\title{
Sistematik Review: Fleksibel Working Arrangement (FWA) Sebagai Paradigma Baru Asn Di Tengah Pandemi Covid-19
}

\section{Systematic Review: Flexible Working Arrangement (FWA) As A New Paradigm Of Civil Servant During Pandemic Covid-19}

\author{
Aulia Annisaa Fadhila, Lungid Wicaksana \\ Program Studi Ilmu Administrasi Negara, Fakultas Ilmu Sosial dan Politik, \\ Universitas Sebelas Maret \\ email: fadhila1594@gmail.com, wlungid@gmail.com
}

\begin{abstract}
Abstrak
Pandemi Covis-19 menjadi tantangan tersendiri bagi pemerintah dalam menentukan arah kebijakan yang berkenaan dengan sistem kerja pegawai, dalam hal ini khususnya Aparatur Sipil Negara (ASN). Paradigma baru dibangun untuk menciptakan budaya kerja yang lebih fleksibel dan adaptif terhadap situasi krisis. Kebijakan Flexible Working Arrangement (FWA) melalui Work From Home (WFH) dan Flexy time menjadi alternatif kebijakan menyikapi hal tersebut. Penulisan ini menggunakan metode Systematic Review dengan Logika Boolean melalui logika “AND” sebagai dasar pencarian jurnal internasional dibeberapa database yang telah dipilih melalui serangkaian prosedur. Dalam pelaksanaanya FWA memiliki beberapa faktor yang mempengaruhi seperti gender, infrastruktur dan teknologi, kepemimpinan dan manajerial, kebijakan, serta jenis pekerjaan dan jabatan. Adapun hasilnya menunjukan bahwa penerapan FWA mengalami tren positif dengan antusias tinggi dibarengi dengan tingkat produktivitas tinggi melalui sistem kerja yang sesuai dengan kebutuhan. Selain itu, terlihat pula manfaat lain dibeberapa aspek yang berhubungan dengan efisiensi, gender, budaya, teknologi, dan transportasi. Namun perlu diperhatikan juga bahwa terdapat beberapa hambatan yang muncul dalam pelaksanaan FWA ini seperti hubungan antara kesiapan teknologi dari instansi dan pegawai, sulitnya pengukuran produktivitas, peran antara kewajiban kantor dan kegiatan rumah tangga, serta masalah psikologis bagi pegawai. Dan pada akhirnya, apabila FWA memang dilakukan dan diterapkan secara optimal akan mendapatkan hasil yang efektif.
\end{abstract}

Kata Kunci: efektifitas; Flexible Working Arrangement; Covid-19 


\begin{abstract}
The COVID-19 pandemic is a challenge for the government to determine a policy related to the work system for employees, especially Civil Servants. A new paradigm was built to create a work system that is more flexible and adaptive to crisis situations. The Flexible Working Arrangement (FWA) policy through Work From Home (WFH) and Flexy time is an alternative policy to overcome this problem. This article applies the Systematic Review method with Boolean logic "AND" as the basis for searching international journals in several selected databases. In its implementation, FWA has several factors that influence its implementation, such as gender, infrastructure and technology, leadership and managerial, policies, and types of employees and positions. The results show that the implementation of FWA is experiencing a positive trend with high enthusiasm supported by high productivity through a work system that suits your needs. In addition, there are also other benefits in several aspects related to efficiency, gender, culture, technology, and transportation. However, it should also be noted that there are several obstacles that arise in the implementation of this FWA, such as the relationship between technological readiness of agencies and employees, the difficulty of measuring productivity, the role between office obligations and household activities, and psychological problems. And in the end, if FWA is done and implemented optimally, it will get effective results.
\end{abstract}

Keywords: effectiveness; Flexible Working Arrangement; Covid-19

\title{
Pendahuluan
}

Sejak instansi kesehatan dunia (WHO) resmi mengumumkan wabah Covid-19 sebagai pandemi global pada awal maret lalu, dalam waktu kurang dari tiga bulan, Covid-19 telah menginfeksi lebih dari 126.00o orang di 123 negara mulai dari Asia, Eropa, AS, hingga Afrika Selatan (Kompas, 2020). Dikutip dari laman WHO Coronavirus Disease (Covid-19) Dashboard (WHO, 2020) per tanggal 21 September 2020, total kasus kumulatif covid-19 di Asia paling tinggi terjadi di India dengan total kasus lebih dari 5 juta orang, disusul Bangladesh lebih dari 300 ribu orang, dan selanjutnya Indonesia dengan kasus lebih dari 200 ribu orang.

Imbas dari adanya pandemi ini terjadi pada lintas sektor seperti perekonomian, bisnis, sosial kemasyarakatan, lingkungan bahkan aktivitas dalam bekerja. Pada sektor ekonomi, para ekonom memprediksikan bahwa sebagian besar negara akan kehilangan setidaknya 2,4 persen dari nilai produk domestik bruto (PDB) mereka selama tahun 2020 (Duffin, 2020). Selain itu pandemi juga berdampak pada sektor pekerjaan. Saat ini 660 juta pegawai dari 20 negara perwakilan, 38 juta pegawai diantaranya atau sekitar 5,7\% dari total pegawai telah mengajukan asuransi pengangguran selama pandemi. (Rothwell, 2020). 
Indonesia sendiri, sebagai negara dengan kasus tertinggi nomor 3 di Asia dengan jumlah kasus terkonfirmasi positif mencapai angka 248 ribu, lebih dari 3,9\% atau sekitar 9 ribu jiwa terkonfirmasi meninggal dunia (Satgas Covid-19, 2020). Adapun tiga provinsi dengan tingkat kasus terbanyak ialah DKI Jakarta dengan jumlah kasus 63.318, Jawa Timur 41.706 kasus, dan Jawa Tengah 19.754 kasus. Data tersebut diambil per tanggal 21 September 2020 (Satgas Covid-19, 2020). Atas banyaknya persebaran virus tersebut, dampak perekonomian pun tidak dapat dihindari. Pandemi Virus Covid-19 setidaknya memberi tiga dampak besar bagi perekonomian Indonesia, pertama konsumsi rumah tangga, kedua menurunya investasi dan ketiga ialah menurunya ekspor komoditas barang (Liputan6, 2020b). Selain kerugian materil, kerugian juga berdampak pada sumber daya manusia khususnya tenaga kesehatan. Direktur Eksekutif Amnesty International Indonesia, Usman Hamid, menyebutkan bahwa Sejak 5 September lalu, setidaknya terdapat 181 tenaga kesehatan yang meninggal dunia, dengan rincian 112 dokter dan juga 69 perawat. Angka tersebut membuat Indonesia menjadi salah satu negara dengan angka kematian tenaga kesehatan terbesar di dunia (Tempo, 2020).

Berbagai klaster penularan muncul di tengah masyarakat, menambah panjang daftar orang yang dinyatakan terkonfirmasi virus tersebut. Khususnya pada sektor publik, klaster perkantoran menjadi salah satu tingginya angka persebaran virus. Sebuah studi di korea selatan menunjukan, 1.143 orang yang dilakukan tes Covid-19 hasilnya adalah 97 terkonfirmasi positif dan 94 diantaranya bekerja di pusat panggilan (call center) pada lantai yang sama. Studi tersebut mengungkap bahwa transmisi virus di dalam kantor lebih besar sekitar 43,5\% daripada penularan yang terjadi di luar kantor. (Park et al., 2020). Selanjutnya beberapa penulis juga menyebutkan bahwa potensi penularan virus covid-19 sangat tinggi pada area tertutup tanpa ventilasi yang baik (Correia et al., 2020).

Di Jakarta sendiri, berdasarkan data Dinas Kesehatan RI per tanggal 7 September, setidaknya terdapat 629 kasus terkonfirmasi positif dari 27 kantor kementerian (Liputan6, 2020a). Menurut Kepala Biro Humas BKN, Paryono (Reporter Satu, 2020), per 21 Agustus lalu, jumlah ASN terkonfirmasi Covid-19 sebanyak 1.324 orang, di mana 802 diantaranya belum sembuh, dan 55 orang dinyatakan meninggal. Menyikapi tingginya angka penularan virus pada sektor publik, Menteri Pendayagunaan Aparatur Negara dan Reformasi Birokrasi (MENPANRB) mengeluarkan Surat Edaran Nomor 58 Tahun 2020 tentang Sistem Kerja Pegawai Aparatur Sipil Negara (ASN) dalam Tatanan Normal Baru sebagaimana terakhir kali diubah melalui SE Nomor 67 Tahun 2020. Di dalamnya telah di atur kriteria penerapan pegawai melalui Work From Home (WFH) dan Work From Office (WFO) berdasarkan peta zona risiko persebaran covid-19 yang dikeluarkan oleh Satuan Tugas Penanganan Covid-19. 
Secara umum Fleksibel Working Arrangement atau FWA merupakan konsep pengaturan kerja fleksibel dengan mengubah pola bekerja yang memungkinkan bagi pegawai untuk dapat memilih waktu bekerja. Pengaturan tersebut meliputi 1) Fleksibilitas penjadwalan jam kerja (Flexy Time); 2) Fleksibilitas jumlah jam kerja (Shifting, Job Sharing); dan 3) Fleksibilitas tempat kerja (WFH) (Georgetown University Law Center, 2006). Karena menurut Kelliher \& Anderson (Simanjuntak; et al., 2019), menjelaskan bahwa implementasi FWA diprediksi dapat menjadi sebuah solusi ke depan untuk meningkatkan kepuasan kerja, komitmen instansi, work life balance dan mendorong pegawai untuk memberikan performa terbaik. Pegawai yang diberikan keleluasaan untuk bekerja diharapkan untuk tetap mencapai output yang optimal, tanpa memperhatikan proses pencapaiannya. Salah satu konsep FWA yaitu Work From Home (WFH), telah banyak diterapkan oleh sebagian besar ASN dalam rangka pencegahan dan pengendalian virus Covid-19 di lingkungan kantor.

Dengan dikeluarkanya surat edaran tersebut, secara tidak langsung telah menggeser paradigma kerja ASN, sebelumnya rata-rata orang yang bekerja selalu pergi ke kantor untuk menyelesaikan pekerjaan atau memberikan pelayanan, namun kini berubah menjadi lebih fleksibel. Pemerintah melalui surat edaran di atas juga telah mengatur persentase maksimal jumlah pegawai ASN yang melaksanakan tugas kedinasan di kantor dengan mempertimbangkan zona risiko wilayah perkantoran instansi pemerintah tersebut. Di Indonesia, konsep FWA telah banyak diterapkan oleh pegawai industri kreatif, seperti media, agensi periklanan, lembaga survei pasar, hingga biro jasa desain dan arsitektur (Duhita dalam Simamora et al., 2019). Sedangkan untuk sektor publik, salah satu konsep FWA yaitu Work From Home (WFH) telah tercetus sebagai wacana kebijakan sejak tahun 2019 untuk mempersiapkan ASN agar seirama dengan Reformasi Industri 4.o. (Kompas, 2019).

Pergeseran metode kerja pada ASN tidak hanya terjadi di Indonesia. Di Queensland-Australia, pemerintah mendorong kebijakan bekerja secara fleksibel bagi pegawai pemerintahan. Hal ini untuk menekan angka persebaran virus pada pegawai, namun tetap memastikan pelayanan publik berjalan lancar. Pilihan bekerja secara fleksibel ini meliputi: 1) Bekerja secara remote (jarak jauh); 2) Waktu mulai dan selesai yang fleksibel; dan 3) Job sharing atau berbagi pekerjaan (Queensland Goverment, 2020). Selain itu berbagai negara di timur tengah juga telah mengubah pola kerja pegawai negerinya saat pandemi, dan tetap memastikan penyediaan layanan publik dengan menggunakan metode pengaturan kerja yang fleksibel. Misalnya pada otoritas Palestina dan Maroko yang telah mengarahkan seluruh kementerian terhubung menggunakan satu intranet, memberikan arahan pada pegawai negeri sipil yang bekerja di 
rumah diberikan komputer dan perangkat lunak yang diperlukan, serta panduan tentang teleworking (sigmaweb, 2020).

Berdasarakan pembahasan diatas, FWA menjadi salah satu solusi alternatif sistem kerja baru yang bisa diterapkan dengan adanya pandemi Covid-19 saat ini. Hal tersebut dilakukan dengan harapan mampu mengurai kepadatan yang ada dikarenakan klaster perkantoran. Dengan demikian, dalam penulisan ini penulis ingin melihat apakah pelaksanaan FWA berjalan efektif atau tidak dengan faktor-faktor yang mempengaruhi diberbagai kasus dan negara. Melalui systematic review dengan Logika Boolean ini, akan tergambar apakah konsep FWA dapat menjadi paradigma baru.

\section{Metode}

Dalam penulisan ini, penulis menggunakan systematic review sebagai metode penulisan. Systematic review sendiri mempunyai kriteria khusus, dimana penelaahan terhadap artikel dilaksanakan secara terstruktur dan terencana yang bertujuan untuk menjawab pertanyaan secara spesifik, relevan dan terfokus (Hariyati, 2010). Siddaway (2019) mencirikan sebuah Systematic review dengan penulisan yang cenderung metodis, komprehensif, transparan, dan dapat direplikasi. Ia menambah bahwa penerapan metode Systematic review melibatkan proses pencarian secara sistematis untuk menemukan semua penulisan yang diterbitkan dan tidak diterbitkan berdasarkan relevansi yang membahas satu atau lebih pertanyaan penulisan, sistematis maupun sintesis dari karakteristik dan temuan hasil pencarian tersebut (Siddaway et al., 2019). Melalui systematic review ini, pencarian terhadap dokumen-dokumen yang digunakan melalui serangkaian prosedur yang telah ditentukan sebelumnya. Menurut (Hariyati, 2010), prosedur yang dilakukan dalam penulisan berbasis systematic review ini mencakup beberapa hal yaitu (1) Pertama, mendefinisikan tujuan dari review dan menetapkan tipe dari evidence yang akan membantu menjawab tujuan review; (2) Pencarian Literatur; (3) Penilaian study; (4) Mengkombinasikan Hasil; dan kemudian terakhir (5) Menetapkan hasil penulisan.

Kemudian, pencarian jurnal secara online dilakukan melalui database yang telah dipilih yang didasari pada Logika Boolean dengan logika AND pada setiap database. Karena ketika satu informasi atau lebih diperlukan untuk membuat keputusan, maka logika AND diterapkan (Houghton \& Houghton, 1999). Ditambah lagi, dengan mengacu pada Jurnal Ilmiah Dan Manajemen Referensi (LIPI, 2019), maka artikel yang dirujuk atau disitasi pada naskah memiliki tingkat kemutakhiran yang memadai minimal 10 tahun terakhir.

Kemudian, dengan mengkombinasikan metode tersebut, penulis menggunakan database internasional sebagai dasar pencarian yang penulis 
khususkan hanya pada pencarian jurnal ilmiah saja. Dengan empat database internasional yang telah dipilih yaitu Emerald Insight, ScienceDirect, Taylor and Francis, dan Sage Journal. Berdasarkan penulisan Aithal (2016) database tersebut merupakan salah satu database dengan jumlah jurnal terbanyak didunia. Ditambahkan pula bahwa database tersebut masuk dalam sepuluh daftar jurnal teratas dalam Google Scholar Metrics (Delgado \& Repiso, 2013). Dengan Logika Booleaan "AND” penulis menggunakan kata kunci "Effetiveness" AND "Flexible Working Arrangement" AND "Covid-19”. Dimaksudkan bahwa pencarian jurnal dalam database tersebut difokuskan pada efektivitas penerapan Flexible Working Arrangement selama masa pandemi Covid-19, dimana database tersebut diakses pada kisaran tanggal 21 September 2020 hingga 24 September 2020.

\section{Hasil dan Pembahasan}

Di bagian ini, penulisan dibagi menjadi dua bagian yaitu (1) Hasil Pencarian dan Kategorisasi Literatur; dan (2) Pembahasan. Didalam Pencarian dan Kategorisasi Literatur dijelaskan bagaimana mekanisme dan prosedur yang digunakan oleh penulis dalam menghimpun artikel dari berbagai sumber yang ada yang kemudian dikategorisasikan berdasarkan pada Quartile atau pengindeksan jurnal berbasis Scopus. Kemudian akan dideskrepsikan ke dalam bagian pembahasan dengan fokus permasalahan pada efektivitas dan faktorfaktor yang mempengaruhi Flexible Working Arrangement (FWA) selama masa pandemi Covid-19.

Pencarian jurnal dilakukan melalui empat database online yaitu Emerald Insight, ScienceDirect, Sage Journal, Taylor and Francis, Garda Rujukan Digital (Garuda), dan Neliti pada kisaran waktu 21 September 2020 hingga 24 September 2020. Penulis menggunakan Logika Boolean dengan logikan AND dan diterapkan menggunakan kata kunci "Effetiveness" AND "Flexible Working Arrangement" AND “COVID” ke dalam database. Melalui mekanisme tersebut setidaknya terdapat 166 hasil literatur jurnal internasional dengan 18 jurnal yang relevan dengan penulisan ini, dengan kategori jumlah setiap Quartile yang berbeda-beda. Hasil pencarian tersebut dijelaskan dalam tabel 1 sebagai berikut:

Tabel 1

Hasil Pencarian Jurnal pada Database Online Internasional

\begin{tabular}{|l|l|c|c|c|c|c|c|}
\hline \multirow{2}{*}{ No } & \multirow{2}{*}{ Database } & Hasil & \multirow{2}{*}{ Relevan } & \multicolumn{4}{|c|}{ Quartile } \\
\cline { 5 - 8 } & literatur & Rele & Q1 & Q3 & Q4 \\
\hline $\mathbf{1}$ & $\begin{array}{l}\text { Emerald } \\
\text { Insight }\end{array}$ & $\mathbf{2 1}$ & 5 & $\mathbf{2}$ & 3 & - & - \\
\hline $\mathbf{2}$ & ScienceDirect & 57 & 5 & 5 & - & - & - \\
\hline
\end{tabular}




\begin{tabular}{|l|l|c|c|c|c|c|c|}
\hline 3 & Sage Journal & 64 & 5 & - & 4 & 1 & - \\
\hline 4 & $\begin{array}{l}\text { Taylor and } \\
\text { Francis }\end{array}$ & 24 & 3 & 2 & - & 1 & - \\
\hline Jumlah & 166 & 18 & 5 & 4 & 2 & 0 \\
\hline
\end{tabular}

Dari Tabel 1 tersebut menunjukan bahwa sebagian besar pencarian jurnal berdasarkan keempat database internasional yang ada sebagian besar tidak relevan. Berdasarkan pencarian tersebut setidaknya hanya $10 \%$ dari keseluruhan jurnal yang relevan dengan penulisan ini. Hal tersebut dikarenakan mayoritas jurnal tidak membahas secara fokus terhadap kajian yang berkenaan dengan Flexible Working Arrangement selama pandemi Covid-19. Meskipun demikian, keseluruhan jurnal internasional merupakan jurnal yang termasuk dalam Quartile 1, Quartile 2, dan Quartile 3 yang bisa dibilang mempunyai kredibilitas jurnal yang telah diakui. Dengan demikian 18 jurnal yang relevan dengan fokus penulisan ini dimanfaatkan penulis sebagai dasar dalam pembahasan masalah yang akan dideskripsikan dalam bagian penulisan selanjutnya.

Dalam pembahasan ini terdapat beberapa bagian yang menjelaskan tentang efektivitas Flexible Working Arrangement selama pandemi COVID dan faktor-faktor yang mempengaruhi hal tersebut. Melalui deskripsi dari hasil pencarian jurnal yang telah dilakukan menunjukan bahwa pelaksanaan Flexible Working Arrangement selama pandemi COVID-19 terjadi di beberapa negara dengan kasus yang berbeda-beda dan dengan faktor yang bermacam-macam. Diyakini bahwa berdasarkan penulisan, penerapan Flexible Working Arrangement berbasis Work From Home (WFH) telah mengalami peningkatan besar selama pandemi (Ollo-López et al., 2020). Peningkatan tersebut adalah upaya pemerintah dalam mengatasi semakin meluasnya penyebaran pandemi ini. Terlebih lagi ketika instansi memberikan pilihan kerja jarak jauh untuk pegawai, mereka akan menyambut baik inisiatifinstansi (Choi, 2020).

\section{a. Faktor-Faktor yang mempengaruhi Flexible Working Arrangement (FWA)}

Penerapan Flexible Working Arrangement ini mempunyai beberapa faktor yang mempengaruhi seperti gender, infrastruktur dan teknologi, kepemimpinan dan manajerial, kebijakan, serta jenis pekerjaan dan jabatan. Faktor inilah yang nantinya akan menentukan bagaimana Flexible Working Arrangement harus dilakukan di lokasi dan situasi yang berbeda-beda. Karena meskipun dengan kasus pandemi yang sama, namun apabila mempunyai unsur faktor yang berbeda maka hasilnya juga akan berbeda.

Pertama, faktor gender, yaitu berkenaan dengan bagaimana penerapan Flexible Working Arrangement berpengaruh terhadap pegawai laki-laki dan perempuan. Penelitian awal menunjukkan bahwa penerapan sistem kerja ini 
didistribusikan secara tidak merata, dimana sistem kerja dari rumah lebih membebani wanita daripada pria (Mallett et al., 2020). Dalam penulisan Feng dan Savani (2020) menunjukan bahwa perempuan merasa kurang produktif dan kurang puas dengan sistem kerja baru dibandingkan laki-laki setelah adanya pandemi ini. Mereka menemukan bahwa kesenjangan gender dalam penelitian tersebut muncul ketika orang tua karier bekerja dari rumah dan tidak memiliki akses terhadap layanan pengasuhan anak. Terlebih lagi, pandemi Covid-19 menyebabkan kesenjangan gender dalam persepsi produktivitas kerja dan kepuasan kerja dimana wanita lebih menderita daripada pria ketika sistem kerja dari rumah diterapkan selama Lockdown Covid-19 (Feng \& Savani, 2020). Akibatnya, menurut Sulivan dan Lewis (dalam Mallett et al., 2020), penerapan sistem kerja ini berpotensi untuk menambah beban rumah tangga perempuan dan melanggengkan marginalisasi perempuan. Temuan ini menunjukkan bahwa ketika instansi menerapkan Work From Home (WFH), seorang pimpinan harus mempertimbangkan efek berbeda dari mode kerja ini terhadap pegawai pria dan wanita (Feng \& Savani, 2020). Disisi lain, Feng dan Savani juga menjelaskan bahwa instansi harus memberikan lebih banyak dukungan seperti halnya penugasan kerja yang fleksibel, tenggat waktu yang fleksibel, dan dukungan sosial kepada pegawai wanita untuk membantu meringankan tekanan yang ditimbulkan oleh model kerja jarak jauh.

Kedua, pengaruh infrastruktur dan teknologi. Dalam melaksanakan konsep FWA infrastruktur teknologi merupakan syarat mutlak yang menunjang kinerja pegawai. Pada berbagai penulisan menyebutkan bahwa pemanfataan teknologi sangat penting untuk menjangkau para pegawai yang bekerja secara remote agar tetap berada di dalam jaringan yang terhubung dengan pimpinan maupun rekan kerja lainnya (Choi, 2020; Hurst, 2020). Selain itu, Parker (2020) menyebutkan bagi instansi yang menerapkan sistem WFH atau bekerja dari rumah harus memastikan ketersediaan komunikasi dan teknologi yang sesuai pada setiap pegawai, sistem teknologi kerja secara virtual, serta pengaturan waktu dan lama jam kerja. Tidak hanya memperhatikan ketersediaan fasilitas bagi pegawai yang melaksanakan $\mathrm{WFH}$, setiap instansi pemerintah juga perlu untuk memfasilitasi pelatihan keterampilan bagi pegawai yang awam terhadap teknologi dan menyediakan sarana teknologi kantor yang mendukung pelaksanaan WFH seperti server, sarana hardware maupun soft ware lainnya (Mallett et al., 2020). Sedangkan untuk menjamin keamananan dan penyalahgunaan data rahasia negara, pemerintah dipandang perlu untuk menyusun protokol terkait kemanan informasi, keamanan siber dan keamanan privasi setiap orang sebagai payung hukum pelaksanaan kerja secara daring (Hurst, 2020; Ollo-López et al., 2020)

Ketiga, faktor kepemimpinan dan manajerial. Banyak penulis mengungkapkan bahwa kepemimpinan dan manajerial memiliki andil yang 
cukup besar dalam pelaksanaan FWA. Faktor kepemimpinan sangat berpengaruh dalam pelaksanaan koordinasi, pencapaian tujuan, serta pola kerja yang tepat selama bekerja secara virtual (Bartsch et al., 2020). Rysavy \& Michalak (2020) menyebutkan bahwa setiap pimpinan harus memiliki metode untuk membangun tim yang kuat dengan teknologi dan layanan virtual. Dia juga menambahkan bahwa untuk menjamin efektivitas koordinasi yang berlangsung secara virtual, pimpinan harus menetapkan pedoman khusus untuk membangun kepercayaan dan komitmen dengan para pegawai. Di sisi lain, terdapat kekhawatiran dari setiap pimpinan instansi pemerintah ketika sistem FWA diimplementasikan pada ASN. Hal ini ditengarai oleh ketidakpercayaan pimpinan apabila output yang telah direncanakan tidak tercapai. Oleh karenanya Choi (2020) berpendapat bahwa setiap pimpinan instansi harus memiliki kendali penuh atas pegawai yang bekerja secara jarak jauh, misalnya dalam rangka menghindari pegawai yang memanfaatkan fasilitas FWA untuk kegiatan yang tidak produktif dan tidak terkait dengan kepentingan pekerjaan maka pimpinan dapat menerapkan aturan dan monitoring ketat yang dibantu teknologi canggih dan termutakhir.

Keempat, faktor kebijakan. Salah satu masalah yang sering terjadi dalam konsep FWA ialah banyaknya pegawai yang salah kaprah memaknai sistem Work From Home (WFH) sebagai cuti, sehingga output dari pekerjaan tidak terpenuhi. Dalam hal ini perlu adanya aturan yang berlaku bagi pegawai agar tetap memperhatikan capaian kinerjanya selama mereka bekerja jarak jauh, juga sebagai bentuk kepatuhan pegawai dalam menjalankan tugasnya (Parker, 2020). Selain hal tersebut, Taskin \& Edwards (dalam Choi, 2020) menambahkan bahwa FWA dapat berjalan baik dengan memperkuat kebijakan birokrasi di dalamnya, misalnya prediktabilitas, akuntabilitas, dan kontrol atas pegawai. Pada dasarnya konsep FWA memberikan kebebasan namun bertanggung jawab atas setiap kewajiban pada pekerjaanya. Di Indonesia sendiri, penerapan kebebasan yang bertanggung jawab tercermin pada pelaksanaan WFH ASN selama pandemi Covid-19. Sebelum diterapkan konsep FWA pada ASN, ASN memiliki kewajiban masuk kerja dan menaati ketentuan jam kerja sebagaimana diatur dalam PP No. 53 Tahun 2010 tentang Disiplin PNS. Dalam PP tersebut mewajibkan bagi setiap ASN untuk datang ke kantor, melaksanakan tugas, dan pulang sesuai ketentuan jam kerja serta tidak berada di tempat umum bukan karena dinas. Adapun total jam kerja ASN yang ditentukan ialah 7,5 jam per hari atau 37,5 jam per minggu. Kebijakan bagi ASN yang mengatur secara rigid dapat menjadi kendala dalam penerapan konsep FWA pada ASN, terutama fleksibilitas waktu dan tempat kerja. Pemerintah dapat meninjau ulang kebijakan tersebut dan melakukan perubahan yang mengatur disiplin pegawai disesuaikan dengan konsep FWA. Hal ini seperti dikemukakan oleh Ollo-López et al., (2020) bahwa seiring perkembangan 
jaman, aturan-aturan terkait ketenagakerjaan sebaiknya dilakukan penyesuaian kembali agar dapat mengakomodir ketentuan bekerja dari mana saja dan kapan saja.

Kelima, faktor terakhir yang mempengaruhi konsep penerapan FWA ialah jenis pekerjaan dan jabatan. Dalam penerapan konsep FWA, tidak semua jenis pekerjaan dapat diberikan kesempatan untuk melaksanakan pekerjaan secara fleksibel. Pada pekerjaan yang memprioritaskan keterampilan seperti IT, programer, dan analis lebih diuntungkan karena dapat melangsungkan pekerjaan jarak jauh (van Barneveld et al., 2020). Adapun jenis pekerjaan bagi ASN yang dikecualikan untuk melaksanakan konsep FWA ialah pekerjaan yang berhubungan secara langsung/tatap muka dengan pengguna layanan baik masyarakat maupun stakeholder lainya. Selain jenis pekerjaan, jabatan juga berpengaruh dalam implementasi FWA. Dalam Ollo-López et al., (2020) menyebutkan jabatan pimpinan tinggi dan jabatan pengambil keputusan lainnya dimungkinkan untuk melaksanakan FWA. Dia menambahkan bahwa hal ini berkaitan dengan keterampilan yang dimiliki oleh orang-orang pada posisi hierarkis dianggap lebih kompeten daripada pegawai yang tidak menduduki level tersebut.

\section{b. Efektivitas Flexible Working Arrangementselama pandemi Covid-19}

Berbagai alasan muncul atas adanya tuntutan penerapan Flexible Working Arrangement. Alasan utama penerapan FWA adalah sebagai alternatif pemecahan masalah karena tingginya angka persebaran Covid-19 yang dilakukan melalui Work From Home dan Flexy time. Selain itu disampaikan oleh Parker (2020), bahwa hal ini dilakukan atas tuntutan untuk mengurangi kepadatan kantor, mendesain ulang sistem kerja yang ada, tata kelola kantor yang berbasis situasi krisis, serta meningkatkan teknologi dalam situasi krisis. Tidak hanya berfokus pada perubahan secara fisik maupun materiil, pemerintah juga harus mampu mendalami tentang permasalahan dan dampak terjadinya pandemi ini. Sejalan dengan hal tersebut, Mallet (Mallett et al., 2020) menjelaskan bahwa disaat pemerintah mulai mempersiapkan faktor resiko dalam sistem kerja $\mathrm{WFH}$, penting untuk pemerintah dan masyarakat berusaha memahami fenomena tersebut secara kritis dan komprehensif. Hal ini dapat diartikan bahwa pemerintah harus memberikan pemahaman kepada masayarakat sebagai pengguna layanan dari instansi pemerintahan bahwa terdapat perubahan pola kerja sebagai akibat dari adanya pandemi. Sehingga diharapkan, masyarakat tidak merasa dirugikan dengan adanya

Melihat dari adanya kompleksitas penerapan Flexible Working Arrangement ini, beberapa penulisan mengungkapkan bahwa penerapan sistem tersebut mendapatkan apresiasi yang cukup positif. Survei terbaru dari 
Beaudoin, Gaskell, Lister, dan Margolies (dalam Parker, 2020) menunjukan bahwa berdasarkan pengalaman pandemi selama penerapan Work From Home, sebagian kecil pegawai lebih memilih untuk bekerja dikantor secara penuh, sementara sebagian besar cenderung memilih untuk membagi waktu bekerja secara virtual dan dikantor secara bergantian sesuai kebutuhan. Sementara itu, mayoritas pekerjaan di Amerika Serikat yang dipengaruhi oleh kebijakan Lockdown, diperkirakan lebih dari setengah dari pegawai tersebut diperbolehkan dan memilih untuk bekerja dari rumah selama pandemi Covid19 (Hurst, 2020). Dari hasil survey tersebut mengindikasikan bahwa penerapan Work From Home disambut baik oleh mayoritas pegawai kantor, dimana mereka menganggap bahwa sistem kerja baru tersebut lebih sesuai dengan kebutuhan. Sebuah studi oleh Beauregard (dalam Mallett et al., 2020) menunjukkan bahwa 75\% pegawai yang menerapkan Work From Home percaya bahwa produktivitas mereka lebih tinggi di rumah daripada di kantor. Dalam kajian lain, Redman (dalam Mallett et al., 2020) juga menunjukan bahwa terdapat hubungan secara positif antara jam kerja di rumah dengan pekerjaan dan kepuasan hidup, kemudian terdapat hubungan secara negatif terkait dengan kelelahan dan stres. Fakta tersebut menjelaskan bahwa para pegawai lebih cenderung merasa bahagia apabila mereka menerapkan sistem kerja secara Work From Home. Selain mampu mengatur waktu mereka secara mudah hal tersebut juga berhubungan erat dengan produktivitas kerja apabila dibandingkan dengan bekerja di kantor. Sehingga dapat dikatakan bahwa, secara keseluruhan, bagi mereka yang bekerja dari rumah, hasilnya menunjukan sebagian besar positif, dengan pegawai dan pemberi kerja samasama menemukan produktivitas yang kurang lebih sama dibandingkan jika pekerjaan diselesaikan dalam pengaturan yang lebih tradisional (Beck \& Hensher, 2020).

Disisi lain, tidak hanya produktivitas yang menunjukan tren positif atas adanya sistem kerja baru ini, terdapat beberapa aspek yang menunjukan bahwa penerapan Work From Home merupakan salah satu alternatif solusi yang tepat dan efektif dalam memecahkan masalah sistem kerja selama pandemi. Karena dalam hal ini penerapan Work From Home dinilai memberikan kebebasan dalam mengatur pola aktivitas sehari-hari berdasarkan kebutuhan individu (Wang \& Ozbilen, 2020). Kebebasan inilah yang menjadi menjadi keuntungan bagi banyak orang dengan potensinya untuk meningkatkan fleksibilitas dan keseimbangan kehidupan kerja (Mallett et al., 2020). Seperti yang telah disampaikan sebelumnya, bahwa dengan bekerja dirumah, pegawai mampu mengelola tingkat stress dan menurunkan kelelahan, sehingga nantinya akan tercipta keseimbangan kehidupan kerja. Dalam penerapnnya sendiri, sistem kerja berbasis rumah lebih banyak digunakan oleh mereka yang tinggal jauh dari tempat kerja (Ollo-López et al., 2020). Hal ini dilakukan dengan alasan 
bahwa pegawai tidak lagi harus sering berpegian ke kantor dengan jadwal yang lebih fleksibel (Beck \& Hensher, 2020)

Selain itu, penerapan Flexible Working Arrangement menunjukan manfaat yang luas yang meliputi berbagai aspek, salah satunya adalah aspek yang berhubungan dengan efisiensi, gender, budaya, teknologi, dan transportasi. Menurut Parker (2020) Work From Home ini dapat menjadi kebijakan yang mampu meningkatkan efisiensi instansi dalam hal penggunaan fasilitas kantor. Terlebih lagi, fasilitas yang digunakan selama FWA adalah fasilitas pribadi, sehingga intensitas penggunaan fasilitas kantor akan sedikit banyak berkurang. Kemudian temuan Feng dan Savani (2020) menunjukan bahwa perubahan di tempat kerja ini dapat membalikkan tren menuju kesetaraan gender yang lebih besar di sejumlah domain pekerjaan. Dimana dalam faktor gender dijelaskan bahwa perempuan merasa lebih dirugikan atas penerapan sistem kerja ini, yang disebabkan oleh adanya tanggung jawab ganda antara pekerjaan kantor dan rumah.

Jika dilihat dari perspektif instansi, maka akan muncul budaya instansi yang mulai mengalami perubahan secara signifikan atas adanya sistem kerja ini. Ollo Lopez (2020) menjelaskan bahwa perusahaan yang memberikan otonomi kepada pegawai dalam masa penerapan FWA akan lebih mendukung penerapan sistem kerja berbasis rumah dari pada instansi dengan pemberian otonomi pegawai yang lebih rendah. Hal tersebut berhubungan dengan fleksibilitas budaya instansi yang cenderung memberikan otoritas kepada pegawai untuk memilih apakah akan menerapkan FWA atau tidak. Karena dengan budaya yang lebih fleksibel dan tidak kaku akan menciptakan instansi yang lebih adaptif terhadap situasi krisis. Selain fleksibilitas budaya instansi tersebut, dalam kajian Bartsch (2020) menunjukan bukti bahwa instansi dengan pemanfaatan teknologi yang lebih matang mampu mempertahankan kinerja tinggi di antara pegawai pada masa krisis. Dari fleksibilitas budaya kerja dan pemanfaatan teknologi sebuah instansi inlah yang nantinya akan menciptakan instansi yang mampu beradaptasi dalam berbagai situasi.

Kemudian, secara tidak langsung, penerapan Flexible Working Arrangement ini juga berpengaruh pada sistem transportasi yang ada. Manfaat ini merupakan hal positif bagi bidang transportasi yang ingin menyelesaikan masalah kemacetan yang terus menerus melalui melalui penciptaan sistem kerja yang lebih fleksibel, dan memang berimplikasi pada prioritas investasi transportasi jangka panjang (Beck \& Hensher, 2020). Munculnya manfaat tersebut memang menjadi bagian yang tidak terpisahkan, karena kebanyakan pengguna moda transportasi baik pribadi maupun umum merupakan bagian dari para pegawai di kota-kota besar. Hal ini merupakan mekanisme penting untuk meringankan beban jaringan transportasi dalam bentuk peningkatan potensi kemacetan akibat kuatnya serapan kendaraan bermotor pribadi dan 
berkurangnya kapasitas pada sistem angkutan karena Physical Distancing (Beck \& Hensher, 2020). Disisi lain, dengan adanya penerapan FWA ini, memunculkan dukungan terhadap sistem moda transportasi yang lebih berkelanjutan dan adaptif terhadap masa kritis. Selain mengurangi kemacetan lalu lintas pada jam sibuk dan emisi kendaraan, hasil penulisan Wang dan Azbilen (2020) menyiratkan bahwa program FWA mendukung kebijakan peralihan ketergantungan mobil kearah pembangunan sistem transportasi yang berkelanjutan.

\section{c. Hambatan Pelaksanaan Flexible Working Arrangement}

Penerapan FWA tidak terlepas dari adanya hambatan baik yang terjadi pada instansi pemerintahan maupun pegawai yang melaksanakan pekerjaan jarak jauh. Hambatan pertama yang umum terjadi disampaikan oleh Parker (2020) adalah ketersediaan ruang kerja dan infrastruktur teknologi pada setiap pegawai yang melaksanakan WFH. Parker juga menambahkan bahwa instansi berkontribusi pada biaya penyiapan dan pemeliharaan infrastruktur yang dibutuhkan oleh pegawai dalam sistem kerja secara virtual. Hal ini diperkuat oleh pendapat Mallett et al., (2020) dimana WFH tidak hanya sebatas pelaksanaan kerja jarak jauh namun juga berimbas pada berbagai macam tagihan yang meningkat. Berbagai aspek tersebut yang mempengaruhi bahwa tidak semua instansi dan pegawai telah siap menerapkan konsep FWA. Selain itu, penggunaan jaringan internet secara masif pada pegawai yang melaksanakan WFH tidak menjamin keamanan komunikasi dan informasi pada setiap pegawai (Banks et al., 2020). Dengan kata lain, disatu sisi teknologi menjadi kebutuhan utama dalam penerapan $\mathrm{WFH}$, namun di sisi lain teknlogi dapat menyebabkan seorang kehilangan privasinya apabila tidak dibarengi dengan sistem keamanan.

Hambatan lainya yang muncul ialah pengukuran produktivitas pegawai yang melaksanakan pola WFH. Pimpinan instansi akan cenderung kesulitan mengukur tingkat produktivitas pegawai tiap harinya, karena tidak mengetahui tidak mengetahui berapa lama pegawai menyelesaiakan suatu pekerjaan (Feng \& Savani, 2020). Ini terjadi karena pada konsep FWA hanya mengutamakan capaian kinerja atau output dari masing-masing pegawai tanpa mengukur produktivitasnya.

Di sisi lain, bagi sebagian pegawai yang membagi peran antara karier dan pekerjaan rumah tangga akan muncul cultural shock terhadap penggunaan teknologi dan tanggungjawab mengelola kegiatan rumah tangga yang dapat mempengaruhi tingkat stress pegawai (Bartsch et al., 2020). Adanya gangguan dari anggota keluarga dan persoalan lainnya yang terjadi pada rumah tangga menimbulkan ketidakmampuan pegawai untuk berkonsentrasi lebih baik pada 
pekerjaan (Beck \& Hensher, 2020). Hal tersebut diamini oleh Carnevale \& Hatak, (2020) yang menyebutkan bahwa potensi konflik antara pekerjaan dan lingkungan keluarga mungkin lebih besar dari sebelumnya ketika pegawai menerapkan pola WFH. Konflik antara pekerjaan dan kegiatan rumah tangga yang berkepenjangan dapat menimbulkan berbagai dampak negatif bagi pegawai. Pada kasus yang lebih ekstrim, menurut Guardian (dalam Mallett et al., 2020). insiden kekerasan dalam rumah tangga serta tingkat perceraian dapat muncul sebagai salah satu efek domino penerapan WFH.

Beberapa peneliti memperingatkan bahwa pegawai yang menerapkan WFH dapat menderita masalah psikologis seperti anti sosial, frustasi, ketidakpuasan kerja yang pada akhirnya dapat menyebabkan komitmen yang lebih rendah terhadap instansi (Choi, 2020). Lebih lanjut diungkapkan dalam penelitian, ada beberapa kekurangan dalam pola WFH dibandingkan bekerja di kantor. Kelemahan tersebut termasuk perasaan tidak dilibatkan, ekspektasi produktivitas yang tidak akurat oleh rekan kerja dan pimpinan instansi, dan kebutuhan akan keterampilan dan pola pikir baru yang berbeda. (Rysavy \& Michalak, 2020)

\section{d. Potensi Masa Depan Flexible Working Arrangement}

Semakin mewabahnya Covid-19 ini menjadikan berbagai macam metode dan sistem kerja yang bervariatif. Dengan adanya Wabah COVID-19 ini akan mempercepat tren Flexible Working Arrangement, dan mungkin akan berpotensi untuk jangka panjang (Wang \& Ozbilen, 2020). Bahkan FWA sendiri telah terkonsepkan sejak lama sebelum terjadinya wabah ini. Jika dikaji ulang dan dikaitkan dengan situasi krisis, alternatif ini akan menjadi kebijakan yang lebih adaptif dan cenderung bertahan lama. Sejalan dengan pemikiran tersebut, Parker (2020) menjelaskan bahwa hal tersebut tampaknya menjadi potensi yang dapat diterapkan secara jangka panjang bahkan pasca Covid-19, dengan maksud untuk mengkonfigurasi dan mendesain ulang sistem, prosedur, mekanisme hingga tata ruang kantor secara fisik untuk meningkatkan efesiensi serta mencegah persebaran pandemi. Beck dan Hensher (2020) pun menambahkan bahwa penerapan WFH dimungkinkan bertahan dalam jangka panjang dan merupakan investasi yang berharga dalam kebutuhan masa depan yang lebih adaptif. Namun perlu digarisbawahi bahwa menurut O’Neill (dalam Mallett et al., 2020) sistem kerja tersebut dapat menjadi pedang bermata dua, karena mendukung adanya fleksibilitas kerja tetapi secara bersamaan cenderung meningkatkan jam kerja sehingga sulit untuk menentukan dampak pada keseimbangan kehidupan kerja dan hubungan dengan keluarga. Dengan demikian, hal ini adalah tanda-tanda awal yang positif sebagai bagian yang lebih besar dari investasi masa depan, dimana internalisasi sistem FWA akan 
membentuk sebuah rutinitas baru dalam perubahan sistem kerja dimasa pandemi (Beck \& Hensher, 2020).

Adapun dari potensi tersebut beberapa pendapat dan penulisan memaparkan rekomendasi kesusksesan pelaksanaan FWA. Menurut Gioe et al (2020) sistem WFH dan fleksibilitas ini harus diterapkan sebagai opsi untuk mempersiapkan apabila situasi krisis kembali datang. Selain itu, Khanna et al (2020) juga memberikan prinsip-prinsip kesuksesan FWA sebagai berikut (1) Memprioritaskan hubungan dengan memastikan komunikasi efektif dan harmonis antar pegawai; (2) Menyediakan ruang virtual yang memfasilitasi interaksi santai selama waktu istirahat; dan (3) Menjaga kepercayaan dengan mengutamakan transparansi dan kesetaraan. Lebih lengkapnya lagi Jack Altman (dalam Rysavy \& Michalak, 2020) menjelaskan bahwa terdapat lima petunjuk kesberhasilan FWA, yaitu (1) Menentukan ekspektasi sejak awal sesuai dengan tujuan yang akan dicapai; (2) Pertemuan virutal secara teratur untuk membangun hubungan dan kepercayaan; (3) Memberikan pendapat dan umpan balik atas adanya pendapat secara singkat dan jelas; (4) Manajer harus secara rutin menanyakan perihal pekerjaan dan keadaan pegawai; (5) Manajer harus membangun kepercayaan kepada pegawai dan tidak boleh berasumsi bahwa pegawai yang bekerja dirumah sedang bermalas-malasan.

\section{Penutup}

Berdasarkan pembahasan diatas maka dapat disimpulkan bahwa pelaksanaan Flexible Working Arrangement (FWA) dibeberapa kasus mampu dikatakan efektif dengan respon pegawai yang merasa bahwa dengan sistem kerja tersebut lebih leluasa mengatur jadwal kerja, lebih bahagia, lebih produktif, dan lebih dekat dengan keluarga. Bahkan manfaat lainnya yang secara tidak langsung bisa dirasakan adalah seperti efisiensi, gender, budaya, teknologi, dan transportasi Dijelaskan sebagai berikut (1) Kantor mendapatkan manfaat dalam efisiensi anggaran dari pemanfaatan fasilitas kantor; (2) Munculnya potensi dari kebijakan yang mengarah pada afirmatif gender; (3) Mengubah budaya kerja yang lebih fleksibel, dinamis, dan adaptif; (4) Instansi dengan pemanfaatan teknologi yang lebih matang akan mampu bertahan; (5) Mengurangi angka kemacetan dan kepadatan moda transportasi.

Mulai diterapkannya FWA ini pun memunculkan beberapa faktor yang perlu mendapatkan perhatian khusus yaitu (1) Faktor Gender, yaitu tingkat beban kerja antara pegawai wanita dan pria yang masih dinilai memberatkan wanita; (2) Faktor ketersediaan infrastruktur dan teknologi terutama dirumahrumah pegawai dan instansi seperti penyediaan server, ketersediaan layanan virtual, perangkat hardware dan software, serta sistem keamaanan pendukung; (3) Faktor kepemimpinan yang sangat berpengaruh dalam pelaksanaan 
koordinasi, pencapaian tujuan, serta pola kerja yang tepat selama bekerja secara virtual; (4) Faktor Kebijakan, dimana perlu adanya aturan yang berlaku bagi pegawai agar tetap memperhatikan capaian kinerjanya selama mereka bekerja jarak jauh; serta (5) Faktor Jenis Pekerjaan dan Jabatan, dimana dalam penerapan FWA ini tidak semua jenis pekerjaan dapat diberikan kesempatan untuk melaksanakan pekerjaan secara fleksibel.

Disisi lain, muncul pula hambatan dan potensi yang ada atas penerapan FWA. Dijelaskan dalam pembahasan, bahwa hambatan yang muncul meliputi (1) Ketersediaan ruang kerja, infrastruktur teknologi, serta peningkatan biaya dari pemakaian teknologi pada setiap pegawai yang melaksanakan WFH; (2) Kesulitan dalam menentukan tingkat kinerja dan produktivitas pegawai karena masih terkendala dalam hal pengawasan secara real-time; (3) Munculnya cultural shock terhadap penggunaan teknologi, tanggungjawab mengelola kegiatan rumah tangga yang dapat mempengaruhi tingkat stress pegawai, serta gangguan dari anggota keluarga dan persoalan lainnya yang terjadi pada rumah tangga menimbulkan ketidakmampuan pegawai untuk berkonsentrasi; dan terakhir (4) Pengeruh negatif FWA terhadap psikologis mental para pegawai.

Dengan demikian dapat disimpulkan bahwa pelaksanaan FWA di lingkungan instansi pemerintah untuk jangka panjang dapat diterapkan apabila instansi pemerintah memiliki komitmen sesuai dengan faktor-faktor di atas. Selain itu, untuk mendukung pergeseran paradigma budaya kerja, instansi pemerintah juga perlu untuk terus meningkatkan keterampilan ASN guna mendukung penerapan FWA dari mulai pemanfaatan teknologi dan ketersediaan infrastruktur. Meskipun kedepanya tidak semua jenis pekerjaan dan jabatan dapat menerapkan FWA, namun konsep FWA tetap diterapkan dalam rangka paradigma kerja baru, Pengaturan dan monitoring juga perlu diterapkan sebagai bentuk pengendalian terhadap pegawai yang WFH. Dengan demikian, kontrol dari pejabat terhadap pegawainya tetap terpantau. 


\section{Referensi}

Aithal, P. S., \& Aithal, S. (2016). Scholarly Publishing: Why Smart Researcher Hesitate to Publish in/with Top Ranking Journals/Publishers. International Journal of Current Research and Modern Education (IJCRME), 1(1), 1-17. https://doi.org/10.5281/zenodo.62019

Banks, S., Cai, T., de Jonge, E., Shears, J., Shum, M., Sobočan, A. M., Strom, K., Truell, R., Úriz, M. J., \& Weinberg, M. (2020). Practising ethically during COVID-19: Social work challenges and responses. International Social Work, 63(5), 569-583. https://doi.org/10.1177/0020872820949614

Bartsch, S., Weber, E., Büttgen, M., \& Huber, A. (2020). Leadership matters in crisis-induced digital transformation: how to lead service employees effectively during the COVID-19 pandemic. Journal of Service Management. https://doi.org/10.1108/JOSM-05-2020-0160

Beck, M. J., \& Hensher, D. A. (2020). Insights into the impact of COVID-19 on household travel and activities in Australia - The early days of easing restrictions. Transport Policy, 99(August), 95-119. https://doi.org/10.1016/j.tranpol.2020.08.004

Carnevale, J. B., \& Hatak, I. (2020). Employee adjustment and well-being in the era of COVID-19: Implications for human resource management. Journal of Business Research, 116(May), 183-187. https://doi.org/10.1016/j.jbusres.2020.05.037

Choi, S. (2020). Flexible Work Arrangements and Employee Retention: A Longitudinal Analysis of the Federal Workforces. Public Personnel Management, 49(3), 470-495. https://doi.org/10.1177/0091026019886340

Correia, G., Rodrigues, L., Gameiro da Silva, M., \& Gonçalves, T. (2020). Airborne route and bad use of ventilation systems as non-negligible factors in SARS-CoV-2 transmission. Medical Hypotheses, 141(April), 109781. https://doi.org/10.1016/j.mehy.2020.109781

Delgado, E., \& Repiso, R. (2013). The impact of scientific journals of communication: Comparing google scholar metrics, web of science and scopus. Comunicar, 21(41), 45-52. https://doi.org/10.3916/C41-2013-04

Duffin, E. (2020). Impact of the coronavirus pandemic on the global economy Statistics \& Facts. https://www.statista.com/topics/6139/covid-19-impacton-the-global-economy/

Feng, Z., \& Savani, K. (2020). Covid-19 created a gender gap in perceived work productivity and job satisfaction: implications for dual-career parents working from home. Gender in Management. https://doi.org/10.1108/GM07-2020-0202

Georgetown University Law Center. (2006). Flexible Work Arrangements: A Definition And Examples. Georgetown University Law Center, 1-4. 
Gioe, D. V., Hatfield, J. M., \& Stout, M. (2020). Can United States intelligence community analysts telework? Intelligence and National Security, oo(oo), 1-17. https://doi.org/10.1080/02684527.2020.1767389

Hariyati, R. T. S. (2010). Mengenal Systematic Review Theory dan Studi Kasus. Jurnal Keperawatan Indonesia, 13(2), 124-132. https://doi.org/10.7454/jki.v13i2.242

Houghton, J. M. ., \& Houghton, R. S. (1999). Decision Points : Boolean Logic for Computer Users and Beginning Online Searchers. Libraries Unlimited, Inc.

Hurst, E. J. (2020). Web Conferencing and Collaboration Tools and Trends. Journal of Hospital Librarianship, 2O(3), 266-279. https://doi.org/10.1080/15323269.2020.1780079

Jooss, S., McDonnell, A., \& Conroy, K. (2020). Flexible global working arrangements: An integrative review and future research agenda. Human Resource Management Review, February, 100780. https://doi.org/10.1016/j.hrmr.2020.100780

Khanna, R., Murnane, T., Kumar, S., Rolfe, T., Dimitrieski, S., McKeown, M., Ejareh dar, M., Gavson, L., \& Gandhi, C. (2020). Making working from home work: reflections on adapting to change. Australasian Psychiatry, 14. https://doi.org/10.1177/1039856220953701

Kompas. (2019). Menpan RB Sebut Wacana ASN Kerja di Rumah Tak Perlu Dibahas Dulu. https://nasional.kompas.com/read/2019/o8/21/16464621/menpan-rbsebut-wacana-asn-kerja-di-rumah-tak-perlu-dibahas-dulu?page=all

Kompas. (2020). WHO Resmi Sebut Virus Corona Covid-19 sebagai Pandemi Global.

https://www.kompas.com/sains/read/2020/o3/12/o83129823/whoresmi-sebut-virus-corona-covid-19-sebagai-pandemi-global?page=all

LIPI. (2019). Jurnal ilmiah dan Manajemen Referensi. Pusat Pembinaan, Pendidikan, dan Pelatihan Lembaga Ilmu Pengetahuan Indonesia.

Liputan6. (2020a). INFOGRAFIS: Klaster Covid-19 di 27 Kantor Kementerian. https://www.liputan6.com/news/read/4360276/infografis-klaster-covid19-di-27-kantor-kementerian

Liputan6. (2020b). Sri Mulyani: Corona Beri 3 Dampak Besar ke Ekonomi Indonesia. https://www.liputan6.com/bisnis/read/4292763/sri-mulyanicorona-beri-3-dampak-besar-ke-ekonomi-indonesia

Mallett, O., Marks, A., \& Skountridaki, L. (2020). Where does work belong anymore? The implications of intensive homebased working. Gender in Management. https://doi.org/10.1108/GM-06-2020-0173

Ollo-López, A., Goñi-Legaz, S., \& Erro-Garcés, A. (2020). Home-based telework: usefulness and facilitators. International Journal of Manpower. 
https://doi.org/10.1108/IJM-02-2020-0062

Park, S. Y., Kim, Y. M., Yi, S., Lee, S., Na, B. J., Kim, C. B., Kim, J. Il, Kim, H. S., Kim, Y. B., Park, Y., Huh, I. S., Kim, H. K., Yoon, H. J., Jang, H., Kim, K., Chang, Y., Kim, I., Lee, H., Gwack, J., ... Jeong, E. K. (2020). Coronavirus disease outbreak in call center, South Korea. Emerging Infectious Diseases, 26(8), 1666-1670. https://doi.org/10.3201/eid2608.201274

Parker, L. D. (2020). The COVID-19 office in transition: cost, efficiency and the social responsibility business case. Accounting, Auditing and Accountability Journal, 202O(February). https://doi.org/10.1108/AAAJ06-2020-4609

Queensland Goverment. (2020). Flexible work and COVID-19. https://www.forgov.qld.gov.au/flexible-work-and-covid-19

Reporter Satu. (2020). Kasus PNS Terpapar Covid-19 Sudah Lampaui Angka 1.ooo. https://reportersatu.com/kasus-pns-terpapar-covid-19-sudahlampaui-angka-1-ooo/

Rothwell, J. (2020). The effects of COVID-19 on international labor markets: An update. https://www.brookings.edu/research/the-effects-of-covid-19on-international-labor-markets-an-update/

Rysavy, M. D. T., \& Michalak, R. (2020). Working from Home: How We Managed Our Team Remotely with Technology. Journal of Library Administration, 6o(5), 532-542. https://doi.org/10.1080/01930826.2020.1760569

Satgas COVID-19. (2020). Peta Sebaran. https://covid19.go.id/peta-sebaran

Siddaway, A. P., Wood, A. M., \& Hedges, L. V. (2019). How to Do a Systematic Review: A Best Practice Guide for Conducting and Reporting Narrative Reviews, Meta-Analyses, and Meta-Syntheses. In Annual Review of Psychology (Vol. 70, Issue January). https://doi.org/10.1146/annurevpsych-010418-102803

sigmaweb. (2020). Summary report Reopening public services after the coronavirus (COVID-19) pandemic 10 June 2020. http://www.sigmaweb.org/events/sigma-webinar-reopening-publicservices-coronavirus-crisis-10-june-2020.htm

Simamora, T. V., Mustika, M. D., \& Sjabadhyni, B. (2019). Effects of Flexible Work Arrangements on Ethical Decision Making: Job Satisfaction As a Mediator. Jurnal Psikologi TALENTA, 4(2), 113. https://doi.org/10.26858/talenta.v4i2.8486

Simanjuntak;, D. F., Martina Dwi, M., \& Bertina, S. (2019). Pengaruh Flexible Work Arrangement Terhadap Ethical Decision Making: Peran Employee Engagement Sebagai Mediator. Jurnal Diversita, 5(1), 67-75. https://doi.org/10.31289/diversita.v5i1.2327

Tempo. (2020). Amnesty: Kematian Nakes RI Akibat Covid-19 Termasuk 
Tertinggi di Dunia. https://nasional.tempo.co/read/1383181/amnestykematian-nakes-ri-akibat-covid-19-termasuk-tertinggi-di-

dunia/full\&view=ok

van Barneveld, K., Quinlan, M., Kriesler, P., Junor, A., Baum, F., Chowdhury, A., Junankar, P. N., Clibborn, S., Flanagan, F., Wright, C. F., Friel, S., Halevi, J., \& Rainnie, A. (2020). The COVID-19 pandemic: Lessons on building more equal and sustainable societies. Economic and Labour Relations Review, 31(2), 133-157. https://doi.org/10.1177/1035304620927107

Wang, K., \& Ozbilen, B. (2020). Synergistic and threshold effects of telework and residential location choice on travel time allocation. Sustainable Cities $\begin{array}{lll}\text { and Society, } & \text { 63(August), }\end{array}$ https://doi.org/https://doi.org/10.1016/j.scs.2020.102468

WHO. (2020). WHO Coronavirus Disease (COVID-19) Dashboard. https://covid19.who.int/table 